\title{
From Covenant to Charter: A Legacy Squandered?
}

\author{
Nigel D. White \\ Professor of Public International Law, University of Nottingham, \\ Nottingham, UK \\ nigel.white@nottingham.ac.uk
}

\begin{abstract}
The "Covenant" embodied the idea of a contract for peace in 1919. The "Charter" of 1945 appeared more boldly to embody a world constitution for peace. This article analyses the United Nations and its predecessor organisation, the League of Nations, to demonstrate how each organisation was primarily a product of the conflict that preceded it and how each captured the post-war status quo. Despite this shared backward-looking aspect, both treaties were sufficiently broad to accommodate significant constitutional developments with the potential to shape the collective security systems to meet changing geopolitical conditions. Members of the League failed to seize this opportunity but the promise of an improved collective security system, moreover one based on fundamental laws, offered by the drafters of the Charter, is found to be problematic. The transference of competence from member states to organisation that marked the transition from League to UN, which, when combined with the legalisation of hierarchy by the Charter, have meant that the UN order, despite appearing to be more obviously constitutionalised, was potentially less able to achieve peace through law than its predecessor.
\end{abstract}

\section{Keywords}

League of Nations - United Nations - Covenant - Charter - peace - collective security - law

\section{1 \\ Introduction}

The "Covenant" of the League of Nations embodied the idea of a contract for peace agreed by the victorious powers at the end of the first global conflict 
in 1919. The "Charter" of the United Nations, adopted at the end of the second global conflict in 1945, appeared more boldly to embody a world constitution for peace. This article analyses the United Nations and its predecessor organisation, the League of Nations, to demonstrate how, despite the visions of a future world order aired prior to the adoption of their constituent treaties, each organisation was primarily a product of the conflict that preceded it signifying that both treaties were primarily drafted to tackle the security crises that preceded their creation. Furthermore, each organisation captured the post-war status quo as shaped by the experiences of the devastating conflicts that preceded their creation. Nonetheless, both treaties were sufficiently broad to accommodate significant constitutional development with the potential to shape collective security systems to meet changing geopolitical conditions. However, the promise of an improved collective security system, moreover one based on fundamental laws, offered by the drafters of the Charter, is found to be problematic. The transference of competence from member states to organisation that marked the transition from League to UN, when combined with the legalisation of hierarchy by the Charter, meant that the UN order, despite appearing to be more obviously constitutionalised, was potentially less able to deliver collective security, more broadly to achieve peace through law, than its predecessor.

The celebrated Victorian poet Alfred Lord Tennyson is famous for showing both the glory and futility of war in "The Charge of the Light Brigade" by the British light cavalry in the Crimean War of 1854 . However, in one of his earlier poems "Locksley Hall" of 1837 the poet showed a clearer aversion to war when he "... dipt into the future, far as human eye could see", and "saw the vision of the world, and all the wonders that would be"; where "the war-drum throbb'd no longer, and the battle flags were furl'd", in the "Parliament of Man, the federation of the world". "There the common sense of most shall hold a fretful realm in awe, and the kindly earth shall slumber, lapt in universal law". ${ }^{1}$ The vision, some eighty years before the League came into being, was of universal organisation bringing peace through universal law.

There were elements of this vision in the outlines of international organisation that started to emerge from the speeches of US President Woodrow

1 Interestingly, cited in the introduction to Paul Kennedy, The Parliament of Man: The Past, Present and Future of the United Nations (2006). 
Wilson during the First World War. In a speech made shortly before Britain began its offensive on the Somme in May 1916, Wilson started to outline his radical vision of a world order in which a "feasible association of nations" would ensure the "right" of "every people to choose the sovereignty under which they shall live". ${ }^{2}$ A form of international organisation to regulate and protect the right to self-determination for peoples was combined with respect for the more orthodox principle of sovereign equality in Wilson's various speeches and writings. Wilson's vision of there being an end to the Great War on the basis of "Peace without Victory", meaning that the war should be brought to an end with both sides agreeing terms on the basis of sovereign equality rather than fighting on in pursuit of a clear victory, was cemented in a speech to the US Senate of 22 January 1917. This peace would be "made secure by the organized major force of mankind", which was to be based not on a "balance of power, but a community of power; not organized rivalries, but an organized common peace". 3

Nonetheless, his January 1917 vision of the League as a "community of power" was modified by Point 14 of his famous Fourteen Points a year later in January 1918, which contained a more orthodox commitment to a "general association of nations ... formed under specific covenants for the purposes of affording mutual guarantees of political independence and territorial integrity to great and small states alike". ${ }^{4}$ This suggested that his previous vision of a "community of power" had been replaced by a template for a more orthodox web of covenants or contracts between sovereign equals that would represent a clearer continuation of the pre-1914 international legal order, albeit with a new universal layer of what McNair termed "a kind of public law transcending in kind and not merely in degree the ordinary agreements between states". ${ }^{5}$

The first draft of the Covenant that appeared in February 1919 was declared by Wilson as a "living thing" and as a "constitution of peace, not as a League of War". ${ }^{6}$ However, he had to return to the Commission in March 1919 to propose changes to the draft Covenant, effectively concessions to state sovereignty, in order to try to persuade Congress. These changes were primarily the inclusion of a withdrawal clause, an exclusion of matters within a member's domestic

2 New Willard Hotel Speech to the League to Enforce Peace, 27 May 1916.

3 Available at: http://www-personal.umd.umich.edu/ ppennock/doc-Wilsonpeace.htm (last accessed on 28 January 2020).

4 Bob Reinalda, Routledge History of International Organizations: From 1815 to the Present Day (2009) pp. 184-6.

5 Arnold D. McNair, "The Functions and Differing Legal Character of Treaties", 11 British Year Book of International Law (1930) pp. 100, 101, 112.

6 Ruth Henig, The League of Nations (2010) p. 38. 
jurisdiction, and recognition of regional understandings such as the Monroe Doctrine. ${ }^{7}$ Despite these changes, British Prime Minister David Lloyd George remained of the opinion that had such a treaty existed in the summer of 1914, war would not have broken out as political leaders would have been forced to discuss and resolve their differences by the processes and machinery of the League. ${ }^{8}$ Nevertheless, there was an indication that leaders were of the opinion that a procedural approach would not stop a government set on a longterm policy of aggression. ${ }^{9}$

Lloyd George's understanding of the League suggests he saw it as achieving peace through legal procedures, rather than any change in the substantive law. This will be shown to be too shallow an analysis of the League, but it raises the question of how peace could be achieved, moreover, how this might be done on the basis of law. The importance of law to peace will be seen throughout the following analysis, but it is useful at this point to highlight the view of Hans Kelsen, writing in 1944 before any draft of the UN Charter had emerged, but with the experience of the League to draw upon. Kelsen argued that "the solution of the problem of a durable peace can only be sought within the framework of international law", otherwise states would continue to be judges in their own cause, deciding when it was in their interests to wage war. Furthermore, it was essential to remove that judgement from states to an independent organisation. However, Kelsen argued that peace through law could not be achieved through the political organs of an organisation. He points to the experience of the League of Nations: "[ $t$ ]his union of States, which is so far the biggest international community to secure international peace, has failed completely". He pointed to a "fatal fault of its construction", namely that "the authors of the Covenant placed at the centre of this international organization not the Permanent Court of International Justice, but a kind of international government, the Council of the League of Nations".10 Kelsen cites a speech made by Prime Minister Winston Churchill to the House of Commons in May 1944 when he stated that: "We intend to set up a world order and an organisation equipped with all the necessary attributes of power in order to prevent future wars or the planning of them in advance by restless and ambitious Nations". The structure would reflect that of the League but the new organisation would be backed by "overwhelming military power". ${ }^{11}$ Kelsen argued that

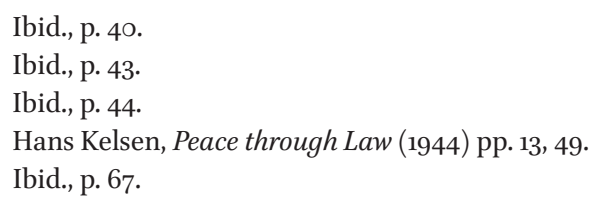


"the more effective the power conferred upon the international organization, the more guarantees which must be given by its constitution that this power will be exercised only for the maintenance of the law; and the only serious guarantee for the legal exercise of power is the provision that the armed forces at the disposal" of the organisation "is to be employed not at the order of a political body but in execution of the decision of a court". ${ }^{2}$

The idea that peace through law could only be achieved by ensuring that an International Court would decide on any dispute or conflict and direct the application of community power in the form of sanctions (economic or military) to address any recalcitrant losing state has undoubted attraction for the rule of law, but it fails to recognise the embodiment of political power that both the Covenant and Charter would encapsulate. In contrast to Kelsen's position, the question then becomes whether peace through law is possible within an organisation dominated by political organs. The genesis of the UN in the Declaration of the United Nations of 1 January 1942 showed the desire to ensure that the organisation to replace the League would have to be able to tackle the sort of aggressions that led to the Second World War, and that, contrary to Kelsen's argument, it would be an executive model of collective security.

President Truman's speech to the final plenary session of the United Nations Conference at San Francisco in 1945 showed concern both with the past and with taking action to prevent such catastrophes from happening again - "if we had this Charter a few years ago - and above all, the will to use it - millions now dead would be alive. If we should falter in the future in our will to use it, millions now living will surely die". Furthermore, he spoke of the need "for a good peace, a lasting peace", in which the "decent peoples of the earth must remain determined to strike down the evil spirit which has hung over the world for the last decade"; and that while the Axis powers had failed (though Japan was yet to surrender at this point) "they will try again." 13

Addressing the problems of the past was, however, balanced by other statements showing that the Charter would be capable of being relevant in the future, moreover, on the basis of both law and action. First, a belief in progress: President Truman spoke about the "continuity of history" with the Charter representing the realisation of the vision of Presidents Woodrow Wilson and Franklin D. Roosevelt. Secondly, a recognition of the Charter as a constitution ("a charter for peace") with comparisons made to the US constitution: "this charter, like our own Constitution, will be expanded and improved as time

\footnotetext{
12 Ibid.

13 In Stephen C. Schlesinger, Act of Creation: The Founding of the United Nations (2003) pp. 289-94.
} 
goes on". Third, a preview of later constitutional normative development with the expectation of "the framing of an international bill of rights", which "will be as much a part of international life as our own bill of rights is a part of our Constitution" - the Universal Declaration of Human Rights was adopted by the General Assembly in 1948. In a strange way, President Truman's closing sentence echoes the dreams of Alfred Lord Tennyson: "Let us not fail to grasp this supreme chance to establish a world-wide rule of reason - to create an enduring peace under the guidance of God". ${ }^{4}$

\section{3}

\section{Drafting to Maintain the Sovereignty of the Major Powers}

Despite the rhetoric of American Presidents Wilson and Truman, the drafting of both the Covenant and the Charter demonstrated that law and justice were to be subject to power especially as embodied in the sovereignty of the major powers. Nonetheless, in some ways the Covenant could claim to embody a stronger version of "peace through law" than the Charter. In the preamble of the Covenant, the stated purposes of achieving international cooperation and peace and security were to be achieved by: accepting "obligations not to resort to war"; having "open, just and honourable relations between nations"; establishing "understandings of international law as the actual rule of conduct among Governments"; and by a "scrupulous respect for all treaty obligations". These commitments were explained by: the vestiges of Wilsonian idealism that remained in the final draft; the belief that correct and open legal procedures would have prevented the outbreak of the Great War; the Covenant's accurate reflection of the inter-state nature of international law; and finally the Covenant's position as part of a settlement which was not premised on a totally vanquished enemy. Although the Treaty of Versailles became notorious for reparations imposed on Germany, ${ }^{15}$ it was premised on respect for Germany as a nation state, ${ }^{16}$ albeit Germany's period of membership of the League only lasted from 1926-1933. In contrast, the total defeat of Germany at the end of the Second World War led to its dismemberment, a condition that prevailed until the end of the Cold War. The Covenant had respect for sovereign equality at its heart, at least amongst independent sovereign states, while the UN Charter, despite the primacy given to sovereign equality in Article 2(1),

\footnotetext{
14 Ibid.

15 Adam Tooze, The Deluge: The Great War and the Remaking of Global Order (2015) p. 249.

16 Ibid., p. 272.
} 
was premised on Great Power supremacy and the complete defeat and rebuilding of the "enemy" states in the liberal democratic mould. ${ }^{17}$

However, the law in the Covenant was based on sovereign equality and racial inequality. Wilson's radical liberalism was tainted by a belief in the supremacy of "white civilization", ${ }^{18}$ one that prevented the adoption of a universal norm of self-determination for colonial countries and peoples. From Wilson's perspective Germany was fighting to gain an empire, while the UK and France were fighting to keep theirs. ${ }^{19}$ The First World War was in part a battle to continue empires, a dispute over their ownership; it was not a dispute to remove that model, at least until President Wilson became involved. However, even his famous Fourteen Points of January 1918 did not contain a clear declaration of democracy and self-determination for all, rather a "gradated view of the capacity for self-government that was typical of nineteenth-century liberalism". ${ }^{20}$

In this way Wilson shared a vision of the "civilizing" mission of white peoples with Britain, France and the South African statesman (and member of the British delegation to the Paris Peace Conference of 1919), Jan Smuts, who was very influential in shaping both the Covenant and the UN Charter. ${ }^{21}$ It followed that any collective security system would have to accommodate, possibly support, empire. In 1917 Smuts had argued for a Commonwealth of Nations to emerge from the British Empire, which he described as the "only successful experiment in international government", making it clear that the "Commonwealth" would be a continuation of empire, albeit an enlightened one, where dependent peoples would be under the tutelage of democratic civilised nations. ${ }^{22}$ Smuts embodied the view that rejected the autocratic military imperialism of Germany in favour of a liberal form of imperialism offered by Britain. It was that view which eventually prevailed, not only in the Covenant in 1919 but, arguably, also in the UN Charter of $1945,{ }^{23}$ at least until empires began to collapse and the UN General Assembly adopted the Declaration on Decolonisation of $1960 .{ }^{24}$ In 1919 the "British Empire had never been so large, and much of this was thanks to the new international organization that Smuts

\footnotetext{
17 See the enemy states clauses in Articles 52, 77 and 107 of the Charter of the United Nations 1945 .

18 Tooze, supra note 15, p. 92.

19 Ibid., p. 45.

$20 \quad$ Ibid., p. 121.

21 Mark Mazower, No Enchanted Palace: The End of Empire and the Ideological Origins of the United Nations (2009) p. 9.

22 Ibid., pp. 37-45.

23 Ibid., pp. 63-5.

24 UN Doc. A/REs/1514 (1960).
} 
had been so influential in bringing into being". ${ }^{25}$ The creation of the UN in 1945 did not disturb this. Mazower notes that the "UN's later embrace of anticolonialism ... has tended to obscure the fact that like the League it was a product of empire and indeed, at least at the outset, regarded by those with colonies to keep as a more than adequate mechanism for its defense". ${ }^{26}$

Britain and France gained both Ottoman and German territories in the settlement at the end of the Great War, albeit as mandatories rather than colonial powers, but as the history of colonialism shows there were many forms of colonialism, ${ }^{27}$ and the mandatory model fitted easily within the range. While the preservation of empire by international organisation did not change in 1945, with colonies being unaffected by the International Trusteeship System and Trusteeship Council put in place in Chapters XII and XIII of the UN Charter, the hegemonic capabilities of colonial states were weakened so that they were no longer able to sustain their empires for much longer after the end of the War.

The sovereignty protected by the Covenant of 1919, and continued by the Charter of 1945, had been firmly embedded in international law as articulated by Max Huber in the Island of Palmas case of 1928. In that seminal case, sovereignty "in regard to a portion of the globe is the right to exercise therein, to the exclusion of any other State, the functions of a State", signifying that in the 19th century "most parts of the globe were under the sovereignty of States members of the community of nations, and that territories without master had become relatively few". ${ }^{28}$ That community of privileged nations was in effective institutionalized in the League, moreover, remained untouched by the UN Charter. ${ }^{29}$

The Covenant of the League of Nations was an attempt to re-shape the world order after 1918 but, as Gregor Dallas writes: "[s]tep back into the Europe of 1918 and one is astonished by how much of the old world still stands".30 Whatever vision prevailed, the League was to be central to it and would either serve to protect the status quo (the vision of UK and France); or to change that (the vision of US). Wilson's vision was gradually revealed to be primarily about the assertion of the US version of liberal capitalism based on an "open door", which envisaged independent states with open markets and therefore open to influence, rather than an absolute assertion of self-determination and

\footnotetext{
25 Mazower, supra note 21, p. 46.

26 Ibid., p. 17.

27 Article 22 of the Covenant of the League of Nations 1919.

28 Island of Palmas Case, (1928) 2 RIAA p. 829.

29 Mazower, supra note 21, p. 17.

30 Gregor Dallas, 1918: War and Peace (2000) p. 24.
} 
democracy. ${ }^{31}$ In its final form the primary purpose of the Covenant was not to upset the old order but to prevent it descending into brutal violence once again. Lloyd George boasted that the Covenant "was really a British production although fathered by President Wilson". ${ }^{2}$

The League was constructed to address the type of diplomatic, political, and legal blunders that led to the First World War, not the sort of deliberate, hegemonic aggression that led to the Second. The UN was borne out of the alliance that defeated the Axis powers, an executive model with a great deal of centralised sanctioning power put into the hands of its primary organ. The UN Charter appeared so much more constitutionally and institutionally developed and "action"-oriented than its predecessor. At the San Francisco Conference in 1945 the Soviet delegate stated that one of the characteristics of the Security Council "was that actions should be fast and effective", pointing to the disastrous "effects of the suddenness of enemy action during the present war". ${ }^{33}$ Smaller states agreed to such a concentration of power on the basis that the Council should protect them from aggression, and "that the interests of great and small powers in peace and security rested fundamentally upon the ability of the great powers to work together". ${ }^{44}$

On 5 March 1945, the US on behalf of itself, China, the USSR and the UK, invited governments that had signed or adhered to the United Nations Declaration of 1 January 1942, and had declared war against Germany or Japan, to participate in the United Nations Conference on International Organization (UNCIO) to be held in San Francisco, beginning on 25 April 1945. At UnCio, delegates worked on the Dumbarton Oaks proposals, agreed in 1944 by the USSR, US and UK, to complete the UN Charter. The Dumbarton Oaks proposals embodied the idea of the five permanent members as the world's police force, while immunising them from any such authority by the veto, ${ }^{35}$ which was further refined at the Yalta Conference of February 1945. UnCiO debates included a discussion of the naming of the new organisation, and it was clear that states deliberately chose the name as a continuation of the wartime alliance. ${ }^{36}$ The Treaty establishing the United Nations organisation, however, appeared at least to embody a stronger notion of law than its predecessor. Kelsen was of the opinion that the term "Charter" was more appropriate for the

\footnotetext{
31 Tooze, supra note 15, pp. 15-16.

32 Henig, supra note 6, p. 28.

33 2nd meeting of Committee III/1 (UNCIO Doc. 130, III/1/3) p. 2.

34 Summary Report of the 5 th meeting of Committee III/1 (UNCIO Doc. 263, III1/11) p. 2.

35 For the text of the Dumbarton Oaks proposals see UnCio, vol. 3, pp. 2-17.

36 Report of the Rapporteur, Subcommittee I/1/A, Section 3, to Committee I/1 (UNCIO Doc. $785, \mathrm{I} / 1 / 27)$.
} 
"constitution of the international community" than "Covenant", which he described as referring to a "contractual form of the contents". ${ }^{37}$ This was misleading according to Mazower, for whom the UN reflected a "waning confidence in international law as an impartial expression of civilization". ${ }^{38}$ Furthermore, the Charter's "universalizing rhetoric of freedom and rights was ... a veil masking the consolidation of a great power directorate". ${ }^{39}$

The first version of the UN Charter - the Dumbarton Oaks proposals of 1944 - was essentially directed at Germany and Japan as continuing to pose the greatest threat, as they were still immensely powerful (at least outwardly) in 1944. Hence, the idea of the world's police forced based on the wartime alliance continued into the post-1945 era. German and Japanese aggression had clearly been planned, rather than stumbled into and, therefore, required executive-style government to prevent it happening again. The consensus at Dumbarton Oaks and San Francisco wrongly assumed that the "wartime unity of purpose among the Great Powers would be a permanent feature of their international relations". ${ }^{40}$ Thus, according to Brierly, the "desire for a system of security ready always for immediate action, which was a leading motive behind the substitution of the Charter for the Covenant, has resulted in a system that be jammed by the opposition of one single Great Power". ${ }^{41}$ Tellingly, Brierly surmised in 1946 that "instead of limiting the sovereignty of states we have actually extended the sovereignty of the Great Powers, the only states whose sovereignty is a still a formidable reality in the modern world".42

The UN was built on prosecuting a war against powerful states by (even more) powerful states, but the Second World War had fundamentally changed the balance of military powers so that the enemy was no longer the defeated states but would potentially come from within the alliance itself. To settle disputes between the new leviathans would require old fashioned diplomacy rather than executive action; settlements in which international law would play little or no role. The focus on protecting the sovereignty of the great powers meant that disputes involving them would not be settled by law, only by power or by adjustments to the balance of power.

\footnotetext{
37 Hans Kelsen, The Law of the United Nations: A Critical Analysis of Its Fundamental Problems (1950) p. 3 .

$38 \quad$ Mazower, supra note 21, p. 16.

39 Ibid., p. 7.

40 James L. Brierly, "The Covenant and the Charter", 23 British Yearbook of International Law (1946) pp. 83, 91.

41 Ibid., p. 91.

42 Ibid., p. 93.
} 


\section{Constitutional Potential}

The overriding concern to protect the sovereignty of the victorious states emerging from both World Wars raises the question of whether the drafters of the Covenant and then the Charter created organisations capable of reaching beyond the sovereign interests of individual states by shaping and enforcing a collective security system through marshalling the duties of member states. The Covenant was contained in the first section of the Treaty of Versailles and was seen not only by Wilson but also by the other two leading statesmen "as the key to securing a peaceful Europe and world during the years following the Conference". ${ }^{43}$ Indeed, according to Wilson and Lloyd George the League would be the agency by which the faults in the Versailles system could be corrected. The idea was that the League would adjust the treaties of settlement arrived at the end of the First World War in order to avoid conflict, with Lloyd George stressing its role to "remedy ... repair and redress - the League of Nations will be there as a Court of Appeal to readjust crudities, irregularities, injustices". ${ }^{44}$ Wilson wrote that he realised "more than ever before, that once established, the League can arbitrate and correct mistakes which are inevitable in the treaty we are trying to make at this time". ${ }^{5}$ According to Brierly such adjustments were possible as the provisions of the Covenant were "remarkably informal",46 providing the potential for constitutional growth that could produce a confluence of collective security action based on the rights and duties of member states and the powers of the League.

More specifically, the provisions in the Covenant for peaceful settlement and for enforcement had this potential. Sanctions and armed force envisaged under Article 16 of the Covenant would pit the League and its members against an aggressor but, before that stage was reached, peaceful methods of dispute settlement should have been attempted under Article 15. At the peaceful settlement stage, the League would be an impartial third party, while at the enforcement stage it would shift to managing the duties of member states to take action against an aggressor. The idea of impartiality in the settlement of disputes is evidenced in a detailed draft produced by the French Ministerial commission in June 1918, which included the statement that " $t]$ he object of the League of Nations shall not be to establish an international political State.

43 Henig, supra note 6, p. 36.

44 Ibid., p. 47.

45 Quoted in Alan Sharp, The Versailles Settlement: Peacemaking in Paris 1919 (1991) p. 59.

46 James L. Brierly, "Matters of Domestic Jurisdiction”, 6 British Yearbook of International Law (1925) pp. 8, 15 . 
It shall merely aim at the maintenance of peace by substituting Right for Might as the arbiter of disputes". ${ }^{4}$

One key element in peaceful settlement of disputes by an organisation is the removal of any party to a dispute from blocking a collective response, in other words, from being a judge in its own cause. While the requirement for decisions of the League organs to be made unanimously appeared to be a barrier to effective peaceful settlement, ${ }^{48}$ a careful reading of the Covenant shows that, when compared to the Charter of the United Nations, it was in some ways potentially more effective in preventing a member state from blocking resolutions on matters in which it was involved. Article 15 of the Covenant provided that member states agreed to submit disputes to the Council, which "shall endeavour to effect a settlement of the dispute". If unsuccessful, this resulted in the production of a report by the Council, either unanimously or by majority vote, containing a statement of the facts of the dispute and "the recommendations which are deemed just and proper in regard thereto". Article $15(6)$ stated that if the report was agreed unanimously by members of the Council "other than the Representatives of one or more of the parties to the dispute, the Members of the League agree that they will not go to war with any party to the dispute which complies with the recommendations of the report". This was a significant departure from the basic principle of unanimity found in Article 5, preserving the impartiality of the Council by disregarding the votes of disputants, and potentially leading to enforcement under Article 16 if a party to a dispute disregarded its recommendations. In particular, a great power was unable to block the adoption of a resolution that purported to address it as a party to a dispute. As McNair pointed out, the Report generated in Article 15(6), "which when adopted unanimously (excluding the disputing parties) has certain definite legal consequences, as has been illustrated by the dispute between Italy and Abyssinia", ${ }^{49}$ when sanctions were ultimately imposed by states on Italy despite its opposition. It should be remembered that Italy was one of the great powers in the Council of Four at the Paris Peace Conference and a permanent member of the League's Council along with France, Britain and Japan. ${ }^{50}$ McNair's example shows how the exclusion of disputants from voting under Article 15 could lead to enforcement against a recalcitrant party under Article 16.

Florence Wilson, The Origins of the League Covenant: Documentary History of Its Drafting (1928) p. 19 o.

48 Article 5 of the Covenant of the League of Nations 1919.

49 Arnold D. McNair, "Collective Security", 17 British Yearbook of International Law (1936) pp. 150,155 .

$5^{\circ} \quad$ Article $4(1)$ of the Covenant of the League of Nations 1919. 
Furthermore, Article 16, which envisaged non-forcible and forcible measures being taken against a member state resorting to war in breach of the covenants, provided in paragraph 4 that any such state could be declared to be no longer a member of the League by a vote of the Council "concurred in by the Representatives of all the other Members of the League represented thereon",51 thereby excluding the transgressing state from blocking any measures under Article 16. In effect, the Covenant enabled the League to pursue dispute settlement and enforcement without being stopped by the negative vote of a member state, including those of the great powers, if such a state either was either a party to a dispute or had resorted to war in violation of the Covenant. ${ }^{52}$

Although these provisions of the Covenant were under-utilised, in design they were potentially stronger than Article 27(3) of the UN Charter. This contains the right of veto for each of the five permanent members, but subject to the important caveat that the parties to a dispute (including any of the permanent members) should abstain from voting on resolutions recommending peaceful settlement under Chapter vi of the Charter. As stated by Jenks, "parties to a dispute are to abstain from voting while the Council is discharging its quasi-judicial function of promoting pacific settlement as distinguished from its political function of action for the maintenance of peace and security".53 In other words, the obligation to abstain did not extend to resolutions proposed under Chapter VII. Nonetheless, Article 27 of the UN Charter contains a basic principle of natural justice that "a party to a dispute shall not be a judge of its own cause and shall abstain from voting". ${ }^{4}$

However, the duty to abstain has barely touched the permanent members in practice in that it has been the Security Council that "not only decides whether a dispute has arisen but also, ultimately, who the parties to the dispute are". ${ }^{55}$ In effect, each permanent member has the power of veto over issues of whether there is a dispute and who the parties to it are. It is not just practice that has driven this, but the design of the Charter in which it is impossible to draw a clear line between the Security Council as corporate actor and the powers and

$51 \quad$ Article 16(4) of the Covenant of the League of Nations 1919.

$5^{2}$ There was also an amendment made by the Second Assembly of the League to Article 16, which if it had come into force, would have discounted the votes of the covenant breaker and other immediately affected states - Percy E. Corbett, "What is the League of Nations?" 5 British Yearbook of International Law (1924) pp. 119, 125.

53 C. Wilfred Jenks, "Some Constitutional Problems of International Organizations", 22 British Yearbook of International Law (1945) pp. 11, 39.

54 Ben A. Wortley, "The Veto and the Security Provisions of the UN Charter", 23 British Yearbook of International Law (1946) pp. 95, 102.

55 Andreas Zimmerman, “Article 27", in B. Simma (ed.), The Charter of the United Nations: A Commentary (2012) p. 925 . 
privileges of each permanent member. Under the "chain of events" as depicted by the Great Powers in explanation of the right of veto, they made it clear that their right of veto extended across both Chapters VI and VII UN Charter with with "the important proviso ... for abstention from voting by parties to a dispute". ${ }^{56}$ However, the design of the Charter has allowed each permanent member a veto over proposed resolutions purporting to tackle disputes in which it is a party and, furthermore, this blocking effect clearly could cover client countries of each permanent member. ${ }^{57}$

In design the League's constitutional development appeared to be severely constrained by unanimity seemingly giving every member state a veto, but this was not the case. In considering the unanimity rule, Stone pointed out that, according to Article 4(5), member states whose interests were specially affected by a matter being discussed by the Council were to be invited to sit as a member at the relevant meeting of the Council. This signified that an invited state had the same rights as any other member including the right to vote. ${ }^{58}$ Its blocking ability, however, was curtailed by the provisions of Articles 5(2), 15(4) (5), and Article 16(4) of the Covenant, which discounted the votes of parties to a dispute, as well as practice by the Council which disregarded negative votes in certain cases involving arbitration, ${ }^{59}$ as well as not counting abstentions as violating the unanimity rule. ${ }^{60}$

Furthermore, the requirement of unanimity in Article $5(1)$ of the Covenant was itself not absolute. The provision stated that "[e]xcept where otherwise expressly provided for in this Covenant or by the terms of the present Treaty [of Versailles], decisions at any meeting of the Assembly or of the Council shall require the agreement of all the members of the League represented at the meeting". ${ }^{61}$ League practice, though not entirely consistent, distinguished "decisions" under Article 5(1) where unanimity was required, from recommendations by the Council and Assembly as well as "voeux" (expressions of desire) in the Assembly where majority vote was allowed. ${ }^{62}$ Although there were some debates in the organs of the League about the extent of the unanimity requirement, Stone concluded that the rule "if wisely interpreted" was

$56 \quad$ UnCIO Vol. 11, p. 713 .

57 Wortley, supra note 54 , p. 105.

$5^{8}$ Julius Stone, "The Rule of Unanimity: The Practice of the Council and the Assembly of the League of Nations", 14 British Yearbook of International Law (1933) pp. 18, 20. In contrast, under Article $310 \mathrm{f}$ the UN Charter an invited state does not have voting rights.

59 Stone, ibid., pp. 20-21.

6o Ibid., p. 32 .

61 Article $5(1)$ of the League of Nations Covenant 1919.

62 Stone, supra note 58 , pp. $35^{-7}$. 
not prejudicial to the activities of the Assembly or Council. "The organs of the League, and particularly the Council, have been reluctant to bind themselves more rigidly than necessary, lest they should hinder their action in unforeseen future contingencies". ${ }^{63}$ Although unanimity appeared to be an insurmountable design fault in allowing for League action, constitutional analysis showed that it was not the case either under the provisions for peaceful settlement of disputes or for the collective enforcement of the Covenant.

\section{$5 \quad$ Collective Security and Peace Through Law}

There may be some doubts about whether a "Covenant", in other words a contract albeit a profound one, can deliver collective security. While a contract binds the member states to act together to protect each other from aggression, it does not provide for the exercise of collective power which can direct those member states towards the achievement of peace and security. Essentially under a contractual approach to security, the member states themselves agree between themselves a strategy, whereas under a collective security system an organisation has the function and powers to recommend or require collective action by member states, possibly even to require then to give up some of their military might for the collective good. Moreover, while a "Covenant", indeed a "Charter", may provide the legal basis for collective security, they do not necessarily provide for peace through law, for example, if they allow for states to be judges in their own cause, or for the organisation to disregard the basic tenets of international law in its decisions.

Writing in the period of the League, Fenwick, argued that "collective security" must be based on "the principle of law ... that the collective judgment of the community of nations must replace the right of each State to be the judge in its own case and the collective power of the community be substituted for the old right of the individual State to take the law into their own hands". 64 Fenwick wrote of the "failure of the League", particularly the "failure of the plan of collective security" contained in the Covenant of the League of Nations 1919. He recognised that the other important functions of the League in social and economic activities remained "substantially unaffected by the failure of collective security". However, these achievements appeared to Fenwick "to be of little consequence in the face of the inability of the League to meet the most vital

63 Ibid., p. 42.

64 Charles G. Fenwick, "The 'Failure' of the League of Nations", 30 American Journal of International Law (1936) pp. 506, 5 ०7. 
problem of any legal system - the maintenance of order in the international community and the protection of rights of person and property". ${ }^{55}$ Fenwick's explanation for the failure of the League in collective security was that it did not have "sufficient corporate unity to overcome the conflicts of nationalistic interest within the dominant group of the Great Powers". ${ }^{66}$ In other words, Fenwick was of the view that there had been insufficient concentration of collective competence in the League's organs necessary to establish an effective system of collective security.

Like Fenwick, McNair also commented on the collective security claims of the League in 1936, but his conclusions are radically different. For McNair, the law on the use of force, and for what became known as "collective security", represented a clean break with the pre-1919 international legal order. McNair wrote that prior to 1919 "war itself was no illegality" meaning that the outbreak of war might involve the breach of a specific treaty but it remained "extra-legal rather than illegal". 67 The revulsion caused by the death and devastation of the Great War led to a fundamental change in the international legal order with a significant majority of states effectively pledging themselves to the principle of collective security even though that term did not appear in the Covenant. The potential of this principle had been evidenced by economic sanctions imposed by fifty states against Italy in 1935 for its resort to war in disregard of its covenants to the League: "[i]nstead of the traditional legal indifference to the question of responsibility for the outbreak of war there is substituted machinery for determining the party responsible and for condemning as illegal a resort to war without previously exhausting the machinery of the League for the settlement of disputes". ${ }^{68}$ McNair assessed the balance between individual and collective rights and duties in the new legal order: "[i]n addition to the traditional right and duty of individual self-defence there is created a collective obligation to apply economic pressure in order to restrain an illegal resort to war, with an option to contribute armed force if necessary". 69 The Covenant represented a shift to a prohibitive jus ad bellum governing unilateral action and a permissive collective use of force through the League: "on the one hand, war in breach of the Covenant is made illegal; on the other, force which is collectivized and placed at the service of the international community is made legal".70

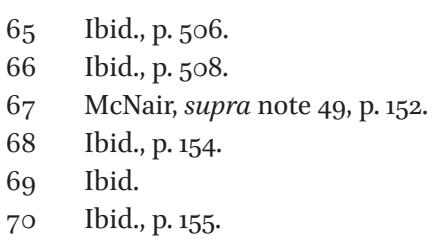


Article 16 of the Covenant only conferred limited powers on the Council of the League - under Article 16(1) member states would decide whether sanctions were due against a member state disregarding its covenants. Under Article 16(2) the Council had the duty to recommend what military measures should be taken against a covenant-breaker in order "to protect the covenants of the League", although Corbett pointed out, drawing on discussions in the League, that this did not prevent member states from deciding to undertake military action in the absence of such a recommendation: 'the main question then ... whether war is to be carried on, is decided not by any of the organs of the League but by each Member for itself'. ${ }^{71}$ In effect, the Council of the League could play a recommendatory role for both sanctions and military measures under Article 16, but it did not replace the duties of member states from taking such measures themselves in the face of a state breaching the covenants of the League. ${ }^{72}$ Although this allowed significant auto-interpretive discretion for each member state into the Covenant system, undermining some of its appeal in providing peace through law, a collective judgment from the Council or indeed, Assembly, would enhance the legitimacy of any security measures taken collectively. In contrast, under the Charter scheme, the judgment of one state could effectively block the exercise of any collective power.

The drafting of the UN Charter was premised on remedying the defects of the League by transferring even greater power to the new organisation in the form of an executive body with the power to decide to impose sanctions or take military action under Chapter VII. Writing at the beginning of the UN period, and also looking back to its predecessor, Brierly viewed the move towards greater constitutionalisation and institutionalisation in the Charter as fraught with problems, by a combination of the veto and the concentration of all significant powers in the hands of the Security Council. ${ }^{73}$

All the references in the Covenant were to the "members of the League" who undertook to act in certain ways except for Article 11(1), which stated that the "League shall take any action that may be deemed wise and effectual to safeguard the peace of nations" - dismissed as a "mere slip in drafting" by Brierly. ${ }^{74}$ Sovereign equality for member states meant exactly that under the Covenant; while under the UN Charter, the move was away from a cooperative model of international organisation towards a crude form of world government at

71 Corbett, supra note 52 , p. 125.

72 John F. Williams, "Sanctions under the Covenant", 17 British Year Book of International Law (1936) pp. 13o, 141.

73 Brierly, supra note 40, p. 85 .

74 Ibid. 
least in matters of peace and security. The Covenant contained the outlines of a constitution, enabling members to adjust the working of the Council and Assembly to suit, whilst the Charter contained details on the powers of each UN organ, in which the power to take action to preserve peace, as determined by the Security Council, is paramount. Universal and, if necessary, overriding obligations were to be created by the Security Council under Articles 25 and 103 of the Charter, but with the purpose of tackling threats to or breaches of the peace not of enforcing international law. During the San Francisco conference, the New York Times observed that the smaller countries, many of which were devastated by war and concerned with simple survival, "reluctantly accepted the idea of virtual world dictatorship by the great powers" in return for having a "world organization" in which they would have some standing. ${ }^{75}$

Writing in 1947, Goodrich identified the main difference between the UN and the League as being the exceptional powers of the Security Council under Chapter viI. Goodrich admitted that nothing could be done against one of the permanent members and, therefore, the UN would have been no more effective in preventing the Second World War than the League. ${ }^{76}$ Those exceptional coercive powers were to operate outside the traditional framework of international law based on consent and cooperation. This is demonstrated by Article 1(1) of the Charter, which references collective measures for the removal of threats to the peace and the peaceful settlement of disputes, but indicates that only the latter should be exercised in "conformity with the principles of justice and international law". Executive action under Chapter viI was to be untrammelled by international law. Even the limited reference to international law and justice was inserted in Article 1 at the insistence of the US delegation at the San Francisco conference, specifically by Senator Arthur Vandenberg, who wanted to leave his mark on the Charter. ${ }^{77}$

The permanent members could, as envisaged by the UN Charter, control the agenda of the most powerful organ, and develop concepts such as "threat to the peace" in Article 39 in a discretionary way, so that selective enforcement fulfilled their common agenda in ways that could sometimes be categorised as the enforcement of universal laws. For example, in the Korean War in the 195os, the lack of centralisation of the US-led military effort did not prevent the relevant actors, including the Secretary-General, from proclaiming the operation as a UN effort to combat lawlessness: "I am conscious of the nobility

$75 \quad$ New York Times, 7 May 1945.

76 Leland M. Goodrich, "From League of Nations to United Nations", 1 International Organization (1947), pp. 3, 10.

77 Schlesinger, supra note 13, p. 161. 
and surpassing significance of United Nations police action in Korea, in which sixteen Member nations actively have taken part. It has been the first determined stand against international lawlessness and aggression which peaceloving nations of the world have taken". ${ }^{78}$ Even "sanctions", which are normally conceptualized legally as measures taken in response to breaches of the law, are imposed in the UN system primarily to address threats to the peace.

The UN has survived because of the total defeat of Germany and Japan enabled universal membership to be achieved, something that the League singularly failed to do. The Charter's privileging of power in the Security Council (and associated treaties such as the Nuclear Non-Proliferation Treaty of 1968) help to explain the UN's longevity. Beyond this: "What started out as a mechanism for defending and adapting empire in an increasingly nationalist age has turned into a global club of national states, devoid of any substantial strategic purpose beyond the almost forgotten one of preventing another world war". ${ }^{79}$ The fact that the Charter was clearly based on the power politics of the post second world war period, and that it has helped cement those configurations of power, explain its survival but, unfortunately, it does not signify an advancement in international law. While the ban on the use of force in Article 2(4) of the Charter appears normatively stronger than the guarantee against aggression in Article 10 of the Covenant, the absence of any possible institutional response to great power infractions undermines its ability to deliver peace through law.

Brierly saw both Charter and Covenant as constitutions, and he took a constitutionalist view of them at least in terms of practice so that they would be "overlaid with precedents and conventions which change them after a time into something very different". ${ }^{80}$ As with all constitutions, the future development of the Charter could not be fully predicted in 1945, and the changes brought by the vast increase in member states representing the first real move towards universal membership, have enabled a form of universal lawmaking not fully envisaged in 1945. There were, however, some signs at San Francisco that the desire of the smaller nations to have an organisation and, moreover, one with a plenary organ where each state, powerful or weak had an equal say, would give rise to the opportunity to shape international relations. In formulating the text of what became Article 10 of the Charter, the discussion at UNCIO was to confer upon the General Assembly the power to discuss any matter "within

78 Trygve Lie, In the Cause of Peace (1954), p. 366.

79 Mazower, supra note 21, p. 27.

8o Brierly, supra note 40, p. 83 . 
the sphere of international relations".81 Although the final text was amended to read "within the scope of the Charter", the Australian delegate expressed the shared view that this was not a significant difference: "That scope will include every aspect of the Charter, everything contained in and everything covered by it. It will include the Preamble of the Charter, the great purposes and principles embodied in it, the activities of all its organs; and the right of discussion will be free and untrammelled and will range over that tremendous area". ${ }^{2}$ Of most significance for international law-making is Article 13(1)(a), which empowered the Assembly to make recommendations for the purpose of "encouraging the development of international law and its codification". At San Francisco this received little specific attention, though it was part of the push back by smaller states against the dominance of the organisation by the Security Council and its permanent members. While these states had little choice but to accept the Dumbarton Oaks version of the Security Council, they managed to secure greater competence for the General Assembly. Kelsen struggled to tie the recommendatory competence in Article 13(1)(a) back to the purposes of the UN except to say that such recommendations would be "measures to strengthen universal peace". ${ }^{83}$ In reality, they allowed the Assembly to reassert the value of law, and offset to a limited degree the dominance of security concerns over law in the Charter.

\section{Concluding Remarks}

The balance between the sovereignty of states and the competence of the organisation achieved in the Covenant of 1919 seemed to be firmly in favour of sovereign states: this is because of the predominance of members' rights and duties as well as the requirement for unanimity in decisions by League organs, thereby seemingly excluding independence of League action. This, combined with a concern to put mainly procedural hurdles in the way of potential aggressors so as to prevent the sort of descent into war that occurred in 1914, provided some narrow indications of an approach to peace based on law, but did not suggest the constitutional potential to create a functioning collective security system. However, the provisions of the Covenant were flexible providing the potential for constitutional growth that could have produced a confluence of collective security action based on the rights and duties of member states and

81 Committee II/2 (UNCIO Doc. 686, II/2/34).

82 4th meeting of Commission II (UNCIO Doc. 1151, II/17) p. 19.

83 Kelsen, supra note 37, p. 215. 
the powers of the League. Flickers of this potential, were seen with the imposition of sanctions against Italy for its invasion of Abyssinia, but they were not nurtured into a fully functioning collective security system.

Furthermore, by exploring the League's broad competence in peace and security, member states could have built a greater deterrent to potential aggressors. While its collective security potential remained underexplored, it is clear that the Covenant and the League had greater potential to address the growing threats than is commonly the view. Moreover, the flaws in its makeup, for example by its lack of clarity on the sanctioning powers of the League in Article 16 of the Covenant, were not remedied by the drafters of the UN Charter; instead they were compounded by dramatically shifting the balance between members' duties and institutional powers towards the organisation and away from member states. Under the Covenant the duties of member states to take collective security action were not dependent upon a Council decision, whereas under the Charter the obligations on member states to take enforcement measures under Chapter vil are dependent upon a decision of the Security Council, in other words dependent upon the decision of each permanent member. Those decisions are unaccountable to the membership or to the International Court of Justice and they embody an approach to collective security that is the antithesis to peace through law. As made clear by Brierly: "we have been led into a cul-de-sac by the over-hasty pursuit of a perfectionist policy, and by a too shallow diagnosis of the causes of failure of the League. By insisting that only an institution which has the power to decide can act effectively we have created one that can neither decide nor act". 84

84 Brierly, supra note 40, p. 93. 